\title{
Intra-annual variation of soil respiration across four heterogeneous longleaf pine forests in the southeastern United States ${ }^{25}$
}

\author{
Althea A. ArchMiller ${ }^{1, *}$, Lisa J. Samuelson ${ }^{2, *}$ \\ School of Forestry and Wildlife Sciences, Auburn University, 3301 SFWS Building, Auburn, AL 36849, USA
}

Keywords: Pinus palustris, soil $\mathrm{CO}_{2}$ efflux, soil temperature, soil moisture, root biomass

1 Abstract

Soil respiration $\left(R_{\mathrm{S}}\right)$ is one of the largest fluxes of net ecosystem exchange and is related to both soil climate and vegetatively driven substrate supply at various spatial and temporal scales. Relationships between the intra-annual variation in $R_{\mathrm{S}}$ and abiotic and biotic variables were examined across diverse longleaf pine (Pinus palustris Mill.) forests to better understand factors related to $R_{\mathrm{S}}$ in these low density, spatially heterogeneous forests. Soil respiration, soil temperature, soil moisture, litter mass, size and proximity of nearby trees, understory cover, and root biomass were measured over 13 months in four longleaf pine forests varying in age from 5 to 87 years. The exponential relationship between $R_{\mathrm{S}}$ and soil temperature accounted for the majority of the intra-annual variation in $R_{\mathrm{S}}$ with a corresponding temperature sensitivity $\left(Q_{10}\right)$ of 2.18. Soil moisture affected the $R_{\mathrm{S}}$-temperature relationship by dampening $R_{\mathrm{S}}$ and $Q_{10}$ during times of extremely dry soil conditions, as defined by soil moisture $\leq 50 \%$ of the texture-derived wilting point, but volumetric soil moisture did not directly correlate with $R_{\mathrm{S}}$. The intra-annual variation in temperature-normalized $R_{\mathrm{S}}$ was negatively related to the distance to nearest tree and ${ }_{5}$ positively related to pine root biomass, but not related to litter mass, understory cover, or stand ${ }_{16}$ structural variables such as stand age, basal area, or tree density. Annual $R_{\mathrm{S}}$ estimates ranged 17 from $12.0 \mathrm{Mg} \mathrm{ha}^{-1}$ of $\mathrm{C}$ in the 5-year-old stand with mostly grass stage seedlings to $13.9 \mathrm{Mg} \mathrm{ha}^{-1}$ ${ }_{18}$ of $\mathrm{C}$ in the dense 21-year-old stand. This study contributes to our understanding of carbon fluxes 19 across diverse longleaf pine ecosystems and indicates the importance of climate in determining the carbon sink potential of southeastern longleaf pine forests.

\footnotetext{
« Prepared for Forest Ecology and Management Special Issue "Forests, Roots and Soil C."

${ }^{*}$ Corresponding author

${ }^{1}$ Email address: aaa0013@auburn.edu; Office: 1-334-844-8061

${ }^{2}$ Email address: samuelj@auburn.edu
} 


\section{Introduction}

The efflux of $\mathrm{CO}_{2}$ from soil, or soil respiration $\left(R_{\mathrm{S}}\right)$, is the dominant flux of $\mathrm{CO}_{2}$ from forests and determines whether forests are carbon sources or sinks (Raich and Nadelhoffer, 1989, GaumontGuay et al. 2006). Intra-annual patterns of $R_{\mathrm{S}}$ generally follow soil temperature and the relationship between $R_{\mathrm{S}}$ and soil temperature has implications for carbon modeling of forested ecosystems, as it is the most commonly used model to calculate annual $R_{\mathrm{S}}$ Reichstein and Beer, 2008; Bahn et al. 2010b: Gomez-Casanovas et al., 2013). However, the temperature sensitivity of $R_{\mathrm{S}}\left(Q_{10}\right)$ has been shown to vary by forest type and age, latitude, and season Knorr et al., 2005, Zhou et al. 2009: Mahecha et al. 2010; Subke and Bahn, 2010), and the $R_{\mathrm{S}}$-temperature relationship may be affected by interactions with other biotic and abiotic factors that directly influence the autotrophic and heterotrophic components of $R_{\mathrm{S}}$ (Chen et al., 2011; Metcalfe et al., 2011). For example, soil moisture may affect $R_{\mathrm{S}}$ in a parabolic manner by limiting root and microbial activity in the soil at low soil moisture levels and restricting $\mathrm{CO}_{2}$ diffusivity at high soil moisture levels Orchard and Cook, 1983, Maier et al. 2010); but an effect of soil moisture is often only detected when field studies capture soil moisture levels low enough to be limiting to $R_{\mathrm{S}}$ or when $R_{\mathrm{S}}$ measurements are frequent enough to discern rapid responses of $R_{\mathrm{S}}$ to soil moisture fluctuations (Palmroth et al. 2005: Reichstein and Beer, 2008; Ford et al. 2012). In addition to soil temperature and moisture, $R_{\mathrm{S}}$ may also be affected by the proximity of nearby trees (Clinton et al., 2011), the amount and type of vegetation cover (Ma et al., 2005; Tjoelker et al., 2005, Fleming et al., 2006; Metcalfe et al. 2011), litterfall (Samuelson and Whitaker, 2012, Oishi et al., 2013), and amount and diversity of root functional groups (i.e. mycorrhizae-infected pine roots versus non-pine roots) (Tjoelker et al. 2005: van Hees et al., 2005, Metcalfe et al., 2011). The effect of many biotic variables, such as vegetation cover, litter mass, and root biomass, are coupled with seasonal increases in soil temperature; therefore, the temperature-independent influence of these variables on $R_{\mathrm{S}}$ can be difficult to quantify.

Soil respiration has been well studied in loblolly pine (Pinus taeda L.), the dominant plantation species in the southern United States, on a variety of sites throughout its range and under varying resource availability and forest management regimes (Samuelson et al., 2004, Wiseman and Seiler, 2004 , Palmroth et al., 2005, Samuelson et al., 2009, Noormets et al., 2010; Oishi et al., 2013 Novick et al. 2014, Tyree et al., 2014, Heim et al., In Press). In contrast, relatively less is known of $R_{\mathrm{S}}$ in longleaf pine ( $P$. palustris Mill.) forests. Longleaf pine forests were once common throughout the southeastern United States (Noss, 1988), and are being actively restored throughout their native range (Hendricks et al., 2006, Brockway et al., 2014). In comparison to intensively 
managed southern pine plantations, longleaf pine forests are typically longer-lived, lower density stands that support high understory vegetation richness and cover, and are managed with frequent prescribed burns to reduce hardwood succession, maintain spatial heterogeneity of the canopy, and promote natural regeneration and native plant diversity (Hedman et al., 2000, Hiers et al., 2003. Mitchell et al., 2006, Archer et al., 2007, Lavoie et al., 2012). Longleaf pine forests are also unique in that they have a relatively open coniferous canopy with a diverse grassland-like understory, and thus may be placed on the nexus between conifer forests, which have relatively lower $R_{\mathrm{S}}$ than deciduous forests, and grasslands, which have relatively higher $R_{\mathrm{S}}$ than forests (Raich and Tufekcioglu, 2000). In previous studies of $R_{\mathrm{S}}$ in longleaf pine forests, $R_{\mathrm{S}}$ was shown to be related to: soil temperature and litterfall in 50-year-old stands varying in basal area (Samuelson and Whitaker, 2012); irrigation treatments in mature stands on excessively drained xeric soils (Ford et al., 2012); canopy scorching in a 22-year-old longleaf pine plantation (Clinton et al., 2011); and soil temperature and soil moisture in juvenile longleaf pine systems grown in control and elevated $\mathrm{CO}_{2}$ open-top chambers (Runion et al. 2012). Given the importance of $R_{\mathrm{S}}$ in quantifying net ecosystem productivity and forest carbon sequestration (Raich and Nadelhoffer, 1989, Lovett et al. 2006), a better understanding of $R_{\mathrm{S}}$ in longleaf pine forests across a range of site and stand characteristics would improve efforts to quantify the carbon sink potential in these forests (Samuelson et al. 2014).

The overall goal of this study was to examine $R_{\mathrm{S}}$ in longleaf pine forests in order to: (1) quantify the intra-annual variation of $R_{\mathrm{S}}$ across a range of stand ages and forest structures; and (2) explore the relationships between $R_{\mathrm{S}}$ and factors related to forest abiotic and biotic factors. Longleaf pine stands ranging in age from 5 to 87 years were studied and represented a range in soil textures, stand structures, and management histories and allowed us to explore variation in $R_{\mathrm{S}}$ not possible with a single study site. Although not a true chronosequence, measurement of $R_{\mathrm{S}}$ in different aged stands can contribute to identifying broad controls over ecosystem carbon exchange (Ryan and Law 2005). We expected that soil temperature would account for the most intra-annual variation in $R_{\mathrm{S}}$ in an exponential manner, but hypothesized that soil moisture would affect the $R_{\mathrm{S}}$-temperature relationship when at biologically limiting levels. Because of varying soil textures between stands, we predicted that the general effect of volumetric soil moisture on $R_{\mathrm{S}}$ may be confounded by soil textural differences (Balogh et al. 2011, Moyano et al. 2012). Therefore, to test for the limiting effect of soil moisture on $R_{\mathrm{S}}$, the influence of both field-measured volumetric soil moisture and texture-derived soil water potential on the $R_{\mathrm{S}}$-temperature relationship were explored. We also examined the relationships between the monthly variation in temperature-normalized $R_{\mathrm{S}}\left(R_{\text {norm }}\right)$ and biotic factors. Finer scale biotic variables (e.g. litter mass, understory cover) were expected 
to vary seasonally and thus account for more variation in $R_{\mathrm{S}}$ than stand structural variables (e.g. stand age, basal area). Specifically, we expected $R_{\text {norm }}$ to linearly increase with proximity to adjacent trees and with increasing litter mass, live root biomass, and understory cover.

\section{Materials and Methods}

\subsection{Study sites and stand descriptions}

Study sites were located at Fort Benning Military Base near Columbus, Georgia, USA $\left(32.38^{\circ} \mathrm{N}\right.$, $\left.84.88^{\circ} \mathrm{W}\right)$. The climate at Fort Benning is subtropical with 30 -year-average minimum, mean, and maximum temperatures of $12.8^{\circ} \mathrm{C}, 18.7^{\circ} \mathrm{C}$, and $24.6^{\circ} \mathrm{C}$, respectively (National Climatic Data Center, 2015a). The 30-year-average monthly temperatures range from highest in July $\left(28.1^{\circ} \mathrm{C}\right)$ to lowest in January $\left(8.4^{\circ} \mathrm{C}\right)$. The 30 -year-average annual precipitation is $1180 \mathrm{~mm}$, spread evenly throughout the year. The soils at Fort Benning are characteristic of highly weathered Ultisols of the southeastern United States, with sandy and loamy sand soils in upland areas and sandy loam and sandy clay loams in lowland areas (Garten and Ashwood, 2004). Fort Benning is within the Southeastern Mixed Forest Preserve and is specifically positioned along the transition zone between the Southern Appalachian Piedmont Section in the northern two-thirds of the base and the Middle Section of the Coastal Plains in the southern one-third (Bailey, 1994).

Four longleaf pine stands were selected for this study, ranging in age from 5 to 87 years (Table 1). The 5-, 12-, and 21-year-old stands were plantations and the 87-year-old stand was a naturallyregenerated, even-aged forest. Stands were located 1 to $9 \mathrm{~km}$ apart and ranged in size from $2.9 \mathrm{ha}$ to 27.3 ha. The 5- and 12-year-old stands were planted at a density of 1494 trees ha ${ }^{-1}$ with containerized seedlings and the 21-year-old stand was planted at 2235 trees ha $^{-1}$ with bare root seedlings. No site preparation details or information on genetic material were available. The soil series dominating each stand were Nankin sandy clay loam, Nankin sandy loam, Troup loamy sand, and Troup loamy sand in the 5-, 12-, 21-, and 87-year-old stands, respectively (Soil Survey Staff, 2014). The 5-year-old stand was located in the Middle Section of the Coastal Plains, which is characterized by rolling to hilly topography with variable textured marine-based sediments (McNab et al., 2005). The other three stands were located within the Southern Appalachian Piedmont Section, characterized by highly weathered and eroded deep clayey soils and a mixture of conifer forest cover types. Frequent, unrecorded burns occurred prior to 1981 because of live fire during military training. Stands were last burned before this study in the winter of 2010 and were on a 1-3 year burn cycle since 2002 (Table 1). No other records besides burn history were available for the 87-year-old stand. More specific information about stand characteristics, including total carbon stocks, can be found in Samuelson et al. (2014). 


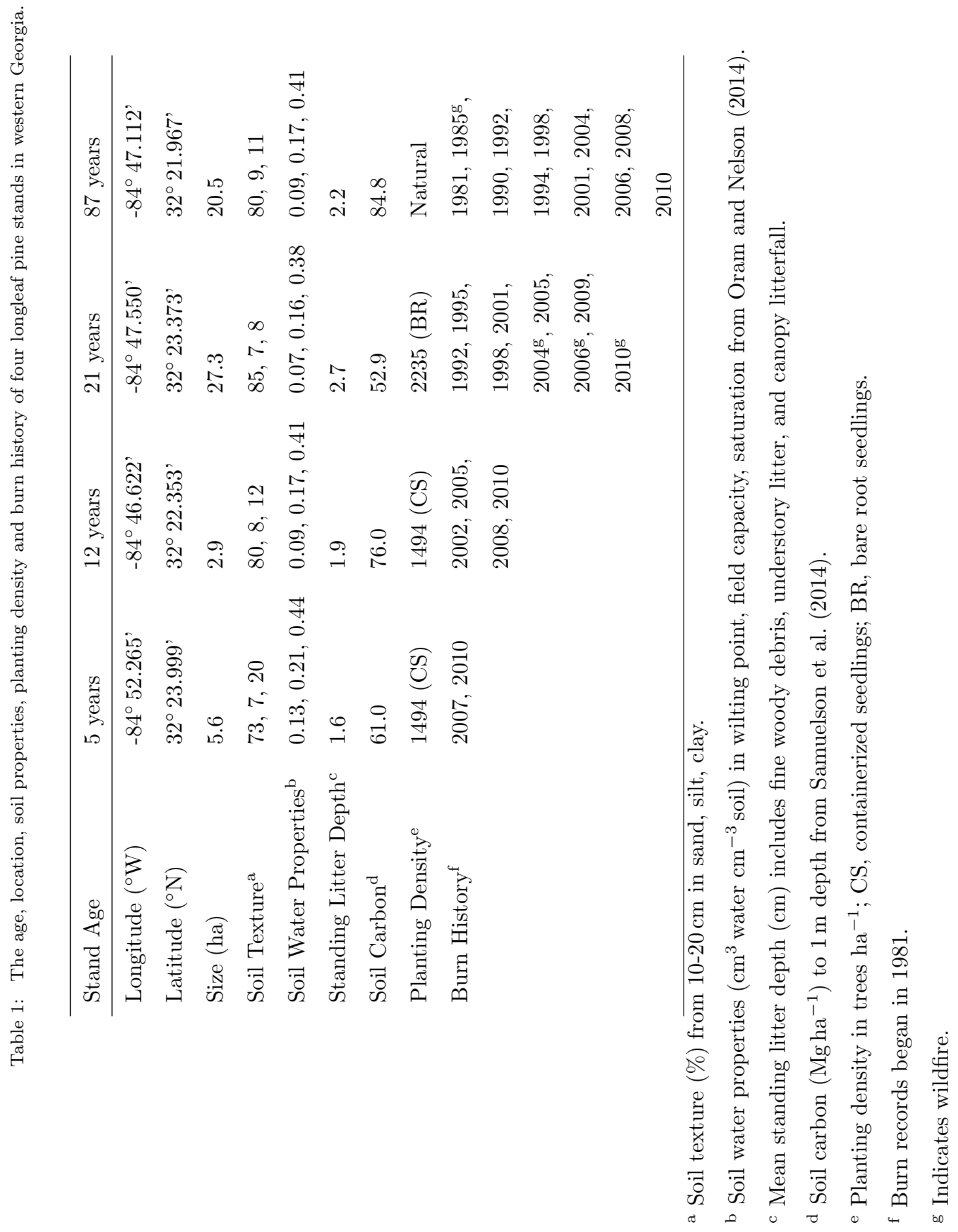


Circular plots one hectare in size were established in each stand. Within each plot, three 25 by $25 \mathrm{~m}$ subplots were placed $35 \mathrm{~m}$ from plot center to the northeast $\left(45^{\circ}\right)$, south $\left(180^{\circ}\right)$, and northwest $\left(315^{\circ}\right)$. Plot centroids were $60 \mathrm{~m}$ apart and were not considered independent. Only two subplots (northeast and northwest locations) were created in the 12-year-old stand due to spacing restrictions from an adjacent study. Stand inventories of each subplot were conducted in February 2012 and included tree species and diameter at breast height $(1.37 \mathrm{~m}, \mathrm{DBH})$. Trees were inventoried if they were taller than $2 \mathrm{~m}$ in height with at least $1 \mathrm{~cm} \mathrm{DBH}$ and classified as saplings $(\mathrm{DBH}<10 \mathrm{~cm})$ or mature trees $(\mathrm{DBH} \geq 10 \mathrm{~cm})$. The four stands represented a range in age and forest structure (Table 2). The youngest stand was a juvenile forest with no mature trees, and a greater proportion of sapling species other than longleaf pine; the 21-year-old stand had trees of a similar size as the 12-year-old stand but at a higher density and basal area; and the 87-year-old stand represented a more mature longleaf pine forest with fewer but larger mature trees and a large cohort of longleaf pine saplings. Understory longleaf pine seedlings and saplings less than $2 \mathrm{~m}$ in height were not recorded in this study, but were were cited in a related study at $625,0,0$, and 500 trees ha $^{-1}$ in the 5-, 12-, 21- and 87-year-old stands, respectively (Samuelson et al., 2014). Only one stand inventory was conducted due to limited site access.

\subsection{Soil respiration and soil environment}

Each 25 by $25 \mathrm{~m}$ subplot was evenly divided into $6251 \mathrm{~m}^{2}$ sampling plots. Beginning in January 2012 , five different sampling plots were randomly chosen from each subplot for measurement of $R_{\mathrm{S}}$ and related variables (55 randomly chosen $1 \mathrm{~m}^{2}$ sampling plots per month). Measurements were conducted monthly from January 2012 through January 2013. Soil respiration, soil temperature, soil moisture, understory vegetation cover, litter mass, and the distance and DBH of the nearest tree to $R_{\mathrm{S}}$ collar were measured at each $1 \mathrm{~m}^{2}$ sampling plot. Soil respiration was measured with a soil respiration chamber head (LI-6400-09) attached to a portable infrared gas analyzer (LI6400, LI-COR Biosciences, Lincoln, NE). Soil respiration collars (PVC, $10 \mathrm{~cm}$ diameter, $4.5 \mathrm{~cm}$ height) were installed in each $1 \mathrm{~m}^{2}$ sampling plot at least 18 hours prior to $R_{\mathrm{S}}$ measurement to reduce the initial flush of $\mathrm{CO}_{2}$ that can occur from soil and litter disturbance and root severing. Collars were inserted in an area free from photosynthetically active vegetation and pushed into the soil through standing litter with $2.5 \mathrm{~cm}$ height remaining above mineral soil. Ambient $\mathrm{CO}_{2}$ concentration (ppm) was measured at the first $1 \mathrm{~m}^{2}$ sampling plot within each subplot and used for the target $\mathrm{CO}_{2}$ concentration across that subplot. To measure $R_{\mathrm{S}}$, the chamber was placed on the collar and $\mathrm{CO}_{2}$ was scrubbed out of the chamber to a level at least $5 \mathrm{ppm}$ below the target $\mathrm{CO}_{2}$ concentration. As soil respiration occurred, chamber $\mathrm{CO}_{2}$ concentration increased and was 
Table 2: Mean stand characteristics of four longleaf pine forests in western Georgia ( $n=2$ to 3 ).

\begin{tabular}{|c|c|c|c|c|c|}
\hline $\begin{array}{l}\text { Stand age } \\
\text { (years) }\end{array}$ & Size class ${ }^{\mathrm{a}}$ & Species $^{b}$ & $\begin{array}{l}\text { Basal Area } \\
\left(\mathrm{m}^{2} \mathrm{ha}^{-1}\right)\end{array}$ & $\begin{array}{r}\text { Density } \\
\left(\text { trees ha }^{-1}\right)\end{array}$ & $\begin{array}{r}\mathrm{DBH} \\
(\mathrm{cm})\end{array}$ \\
\hline \multirow[t]{4}{*}{5} & Mature & LLP & 0.0 & 0 & - \\
\hline & & other & 0.0 & 0 & - \\
\hline & Sapling & LLP & 0.1 & 123 & 3.7 \\
\hline & & other & 0.2 & 475 & 1.94 \\
\hline \multirow[t]{4}{*}{12} & Mature & LLP & 2.1 & 176 & 12.1 \\
\hline & & other & 2.5 & 96 & 16.5 \\
\hline & Sapling & LLP & 2.9 & 768 & 6.8 \\
\hline & & other & 0.2 & 248 & 1.9 \\
\hline \multirow[t]{4}{*}{21} & Mature & LLP & 17.7 & 1259 & 13.2 \\
\hline & & other & 2.2 & 165 & 12.9 \\
\hline & Sapling & LLP & 2.5 & 491 & 7.9 \\
\hline & & other & 0.6 & 176 & 6.7 \\
\hline \multirow[t]{4}{*}{87} & Mature & LLP & 9.9 & 59 & 46.1 \\
\hline & & other & 0.8 & 11 & 26.0 \\
\hline & Sapling & LLP & 0.8 & 699 & 3.6 \\
\hline & & other & 0.0 & 91 & 1.2 \\
\hline
\end{tabular}

${ }^{\text {a }}$ Mature includes trees DBH $\geq 10 \mathrm{~cm}$ and saplings include DBH $\geq 1 \mathrm{~cm}$ and $<10 \mathrm{~cm}$. Height of all measured trees $>2 \mathrm{~m}$.

${ }^{\mathrm{b}}$ LLP, longleaf pine. 
logged by the LI-COR 6400 console until the $\mathrm{CO}_{2}$ concentration was at least 5 ppm higher than the target $\mathrm{CO}_{2}$ concentration. Soil respiration was calculated as the rate of $\mathrm{CO}_{2}$ efflux at the target $\mathrm{CO}_{2}$ concentration based on linear regression of the logged data points $(n \geq 33)$. Soil temperature was measured concurrently with $R_{\mathrm{S}}$ at a $15 \mathrm{~cm}$ depth and within $10 \mathrm{~cm}$ of the collars using a soil temperature probe connected to the LI-6400 system. Volumetric soil moisture was measured across 0 to $20 \mathrm{~cm}$ depth (Hydrosense II, Campbell Scientific, Inc., Logan, UT) within $10 \mathrm{~cm}$ of the collar location at the time of $R_{\mathrm{S}}$ and soil temperature measurement.

\subsection{Vegetation and root variables}

Subsequent to the installation of the $R_{\mathrm{S}}$ collars, the percent of live vegetation cover $(<1 \mathrm{~m}$ in height) was ocularly estimated within the $1 \mathrm{~m}^{2}$ sampling plots and included total cover and individual cover classes of woody plants, vines, forbs, legumes, and graminoid species. Because of the overlapping vertical structure of the canopy layers, the cumulative percentage of individual cover classes could exceed total percent cover. The nearest tree (DBH $>1 \mathrm{~cm}$ and height $>2 \mathrm{~m}$ ) to the $R_{\mathrm{S}}$ collar location was identified and its $\mathrm{DBH}$ and distance to the collar were recorded. Subsequent to $R_{\mathrm{S}}$ measurement, standing litter down to mineral soil within the $R_{\mathrm{S}}$ collar was collected, dried at $70^{\circ} \mathrm{C}$ for 48 hours and weighed. Standing litter mass included fine woody debris, leaf litter from understory species, and litter fall from canopy trees.

Soil samples $\left(10 \mathrm{~cm}\right.$ diameter, $15 \mathrm{~cm}$ depth) were removed from directly below the $R_{\mathrm{S}}$ collars in February, May, and September 2012 and January 2013 for measurement of root biomass by type (live pine, live non-pine, and dead) and size class. Live root size classes included very fine $(\leq 1 \mathrm{~mm})$, fine $(>1$ and $\leq 2 \mathrm{~mm})$, coarse $(>2$ and $\leq 5 \mathrm{~mm})$ and very coarse $(>5 \mathrm{~mm})$. Dead root size classes included coarse $(\leq 5 \mathrm{~mm})$ and very coarse $(>5 \mathrm{~mm})$. Soil was air dried and sifted through a Number 10 sieve. Roots were removed from the soil, sorted, washed, dried at $70^{\circ} \mathrm{C}$ for 72 hours, and weighed. Inventories of soil to $30 \mathrm{~cm}$ depth indicated that approximately $80 \%$ of fine root biomass was in the top $15 \mathrm{~cm}$ (data not shown).

\subsection{Data analysis}

Each set of monthly measurements were averaged by subplot $(n=11$ across all stands per month) and then nonlinear regression and linear mixed-effects analyses were performed to investigate the relationship between $R_{\mathrm{S}}$ and abiotic, biotic, and stand structural variables. All data analysis was completed in SAS (version 9.3, SAS Institute Inc., Cary, NC) with significance level of $\alpha=0.05$. Since there was no true replication of stand ages, differences between stands were not tested. 
The relationship between $R_{\mathrm{S}}$ and soil temperature was modeled using a first-order exponential relationship:

$$
R_{\mathrm{S}}=\beta_{0} * \exp \left(\beta_{1} \mathrm{~T}_{\text {soil }}\right)
$$

where $\beta_{0}$ and $\beta_{1}$ are the fit parameters and $\mathrm{T}_{\text {soil }}$ is soil temperature (PROC NLIN). The temperature sensitivity of $R_{\mathrm{S}}$ was calculated as $\mathrm{Q}_{10}=\mathrm{e}^{10 \beta_{1}}$ and basal $R_{\mathrm{S}}$ was estimated as the intercept $\left(\beta_{0}\right)$ at $\mathrm{T}_{\text {soil }}=0{ }^{\circ} \mathrm{C}$. Annual $R_{\mathrm{S}}$ was calculated for each stand with linear interpolation between measured daily $R_{\mathrm{S}}$ values (Gomez-Casanovas et al., 2013).

To examine the effects of soil moisture $(\theta)$ on the relationship between soil temperature and $R_{\mathrm{S}}$, we analyzed the change in nonlinear trends between $R_{\mathrm{S}}$ and soil temperature during different water status periods (e.g. soil moisture at field capacity versus at wilting point). The soil water categories followed Ma et al. (2005) but were modified to relate volumetric soil moisture to soil texture properties, including wilting point (WP), field capacity (FC), and saturated soil (SS) from Table 1 and Oram and Nelson (2014). The final soil categories included: extremely dry soils $(0 \leq \theta \leq 0.5 \mathrm{WP})$; dry soils $(0.5 \mathrm{WP}<\theta \leq \mathrm{WP})$; moderate soils (WP $<\theta \leq \mathrm{FC}$ ); and wet soils (FC $<\theta \leq \mathrm{SS}$ ). Soils were never measured at levels above saturation, so no soils were considered extremely wet.

To compare trends in Eq. (1) between soil moisture levels, a sum of squares reduction test was completed using the following test statistic:

$$
\text { F-statistic }=\frac{\left(\mathrm{SSE}_{\text {red }}-\mathrm{SSE}_{\text {full }}\right) /\left(\mathrm{df}_{\text {red }}-\mathrm{df}_{\text {full }}\right)}{\mathrm{SSE}_{\text {full }} / \mathrm{df}_{\text {full }}}
$$

where $\mathrm{SSE}_{\text {red }}$ and $\mathrm{SSE}_{\text {full }}$ are the error sum of squares and $\mathrm{df}_{\text {red }}$ and $\mathrm{df}_{\text {full }}$ are the degrees of freedom of the reduced and full models, respectively. The full (or saturated) model had individual $\beta_{0}$ and $\beta_{1}$ parameters fit for each soil moisture category:

$$
\theta=\left\{\begin{array}{rll}
\text { Extremely dry } & : & R_{\mathrm{S}}=\beta_{0 \mathrm{a}} * \exp \left(\beta_{1 \mathrm{a}} \mathrm{T}_{\text {soil }}\right) \\
\text { Dry } & : & R_{\mathrm{S}}=\beta_{0 \mathrm{~b}} * \exp \left(\beta_{1 \mathrm{~b}} \mathrm{~T}_{\text {soil }}\right) \\
\text { Moderate } & : & R_{\mathrm{S}}=\beta_{0 \mathrm{c}} * \exp \left(\beta_{1 \mathrm{c}} \mathrm{T}_{\text {soil }}\right) \\
\text { Wet } & : & R_{\mathrm{S}}=\beta_{0 \mathrm{~d}} * \exp \left(\beta_{1 \mathrm{~d}} \mathrm{~T}_{\text {soil }}\right)
\end{array}\right.
$$

The F-statistic was used to compare reduced models (e.g. Eq.11) with the saturated model and determine whether parameters varied amongst soil moisture categories. This analysis was completed with the SSReductionTest macro in PROC NLIN (Larkin et al., 2012).

The relationships between $R_{\mathrm{S}}$ and stand structural and other biotic variables were explored after the data was temperature-normalized. To calculate temperature-normalized $R_{\mathrm{S}}\left(R_{\text {norm }}\right)$ following 
Maier et al. (2011), observed $R_{\mathrm{S}}$ was divided by the expected $R_{\mathrm{S}}$ value at that soil temperature, which was modeled with:

$$
\theta=\left\{\begin{array}{rll}
\text { Extremely dry } & : & R_{\mathrm{S}}=\beta_{0 \mathrm{a}} * \exp \left(\beta_{1 \mathrm{a}} \mathrm{T}_{\text {soil }}\right) \\
\text { Not extremely dry } & : & R_{\mathrm{S}}=\beta_{0 \mathrm{a}} * \exp \left(\beta_{1 \mathrm{e}} \mathrm{T}_{\text {soil }}\right)
\end{array}\right.
$$

which was the binary model retained from the sum of squares reduction test.

The linear relationship between $R_{\text {norm }}$ and stand structural and other biotic variables (Ys) were tested in the form $R_{\text {norm }}=\beta_{2}+\left(\beta_{3} \mathrm{Y}\right)$ with random coefficients model analyses using PROC MIXED (Littell et al. 2006). Stand structural variables, including subplot basal area, mean DBH, quadratic mean diameter or QMD, tree density, Reineke's stand density index or SDI, and soil sand and clay percentages, were measured once for each subplot. These variables were modeled with the population mean regression intercept $\left(\beta_{2}\right)$ and coefficient $\left(\beta_{3}\right)$ as fixed effects and each month's intercept and coefficient $\left(\beta_{2 i}\right.$ and $\left.\beta_{3 i}\right)$ as random effects, where $i$ represents each month. Reineke's stand density index was calculated following VanderSchaaf (2013). This analysis had no repeated factors.

Biotic variables (i.e. litter mass, understory cover, distance to and diameter of nearest tree, and root biomass) were measured at each $1 \mathrm{~m}^{2}$ subplot per stand per month. These variables were modeled with the population mean regression intercept $\left(\beta_{2}\right)$ and coefficient $\left(\beta_{3}\right)$ as fixed effects. The subplot and the regression coefficients for each subplot $\left(\beta_{2 i}\right.$ and $\left.\beta_{3 i}\right)$ were considered random factors, where $i$ represents each subplot. The 13 monthly measurements were used as repeated measures for this analysis.

In both analyses, covariance structures were chosen by minimizing corrected Akaike information criteria (AICC) for each model individually. The random coefficients were modeled with an unstructured covariance structure including the covariance estimate, a banded covariance structure with the covariance estimate set to zero, or a variance components structure. The repeated factors were modeled with either an autoregressive covariance structure or an autoregressive covariance structure with a moving average.

\section{Results}

\subsection{Variation in abiotic and biotic variables in longleaf pine stands}

Mean monthly air temperature at Columbus, Georgia ranged from $9.9^{\circ} \mathrm{C}$ to $28.8^{\circ} \mathrm{C}$ over the measurement period with the highest temperature in July and lowest in January 2012 (Fig. 1A) (National Climatic Data Center, 2015b). Mean soil temperature exhibited typical seasonal patterns, closely paralleled with air temperature, with an average of $19.1^{\circ} \mathrm{C}$ across stands and over 
the measurement period (Fig. 1B). Total monthly precipitation ranged from $12.4 \mathrm{~mm} \mathrm{month}^{-1}$ to $138.7 \mathrm{~mm}$ month $^{-1}$ (Fig. 1A) (National Climatic Data Center, 2015b). Palmer Drought Severity Index (PDSI) values were above severe drought only during two months, December 2012 and January 2013 (PDSI ranged from -5.23 to 0.26) (National Climatic Data Center, 2014), and monthly precipitation was below the 30-year-average monthly precipitation rates during every month except January, May, September, and December 2012 (data not shown) (National Climatic Data Center 2015a). Mean monthly volumetric soil moisture varied from a low of $1.30 \%$ in May 2012 to a high of $24.57 \%$ in February 2012 and was generally lower in the 21-year-old stand (Fig. 1 C). Within each soil moisture category, mean volumetric soil moisture was generally higher in the 5-year-old stand and lower in the 21-year-old stand relative to the other stands (Table 3).

The mean $\mathrm{DBH}$ of the nearest trees to $R_{\mathrm{S}}$ collars was in general smaller in the 5 -year-old stand (range of $2.7 \mathrm{~cm}$ to $4.3 \mathrm{~cm}$; Fig. 2A). The widest range in $\mathrm{DBH}$ and the largest trees were in the 87 -year-old stand (range $2.4 \mathrm{~cm}$ to $18.7 \mathrm{~cm}$ ). The mean distance to nearest trees was from $0.8 \mathrm{~m}$ to $1.1 \mathrm{~m}$ in the dense 21-year-old stand, and from $1.3 \mathrm{~m}$ to $3.7 \mathrm{~m}$ and $1.6 \mathrm{~m}$ to $3.7 \mathrm{~m}$ in the 5 - and 87-year-old stands, respectively (Fig. $2 \mathrm{~B}$ ). The mean DBH and distance to the nearest tree in the 12-year-old stand ranged from $4.9 \mathrm{~cm}$ to $12.2 \mathrm{~cm}$ and $1.2 \mathrm{~m}$ to $1.9 \mathrm{~m}$, respectively. Mean monthly litter mass was in general higher in the two oldest stands than in the two youngest stands and ranged from $3.0 \mathrm{Mg} \mathrm{ha}^{-1}$ to $15.2 \mathrm{Mg} \mathrm{ha}^{-1}$ across stands (Fig. $2 \mathrm{C}$ ).

Seasonal variation in total percent vegetation cover was evident in all stands but less pronounced in the denser 21-year-old stand (Fig. 3). In the 21-year-old stand, peak total vegetation cover was generally lower than in the other stands and its understory was dominated by forb cover, such as Pityopsis gramnifolia (Michx.) Nutt., and woody cover (mainly Toxicodendron spp.). Grasses dominated the understory of the other three stands, followed by woody cover in the 12- and 87year-old stands and woody and forb cover in the 5-year-old stand. Across all stands, annual mean vine and legume percent cover were $8.0 \%$ and $3.8 \%$, respectively.

Mean root biomass values by type, size class, and sampling month are shown in Figure 4. Total live root biomass was as high as $20.4 \mathrm{Mg} \mathrm{ha}^{-1}$ in the 21 -year-old stand, but in the other stands did not exceed 15.2 $\mathrm{Mg} \mathrm{ha}^{-1}$. In the 5-year-old stand, non-pine root biomass was greater than pine root biomass during each sampling month, and in the 21-year-old stand, pine root biomass was greater than non-pine root biomass during each sampling month. In the 12-year-old stand, the relative contribution of pine and non-pine roots varied by sampling month, and in the 87-year-old stand, non-pine and pine roots had similar biomass quantities. On average, very fine, fine, coarse, and very coarse roots comprised $61,16,16$, and $7 \%$ of total non-pine root biomass, respectively, and $40,17,15$, and $28 \%$ of total pine root biomass, respectively. 

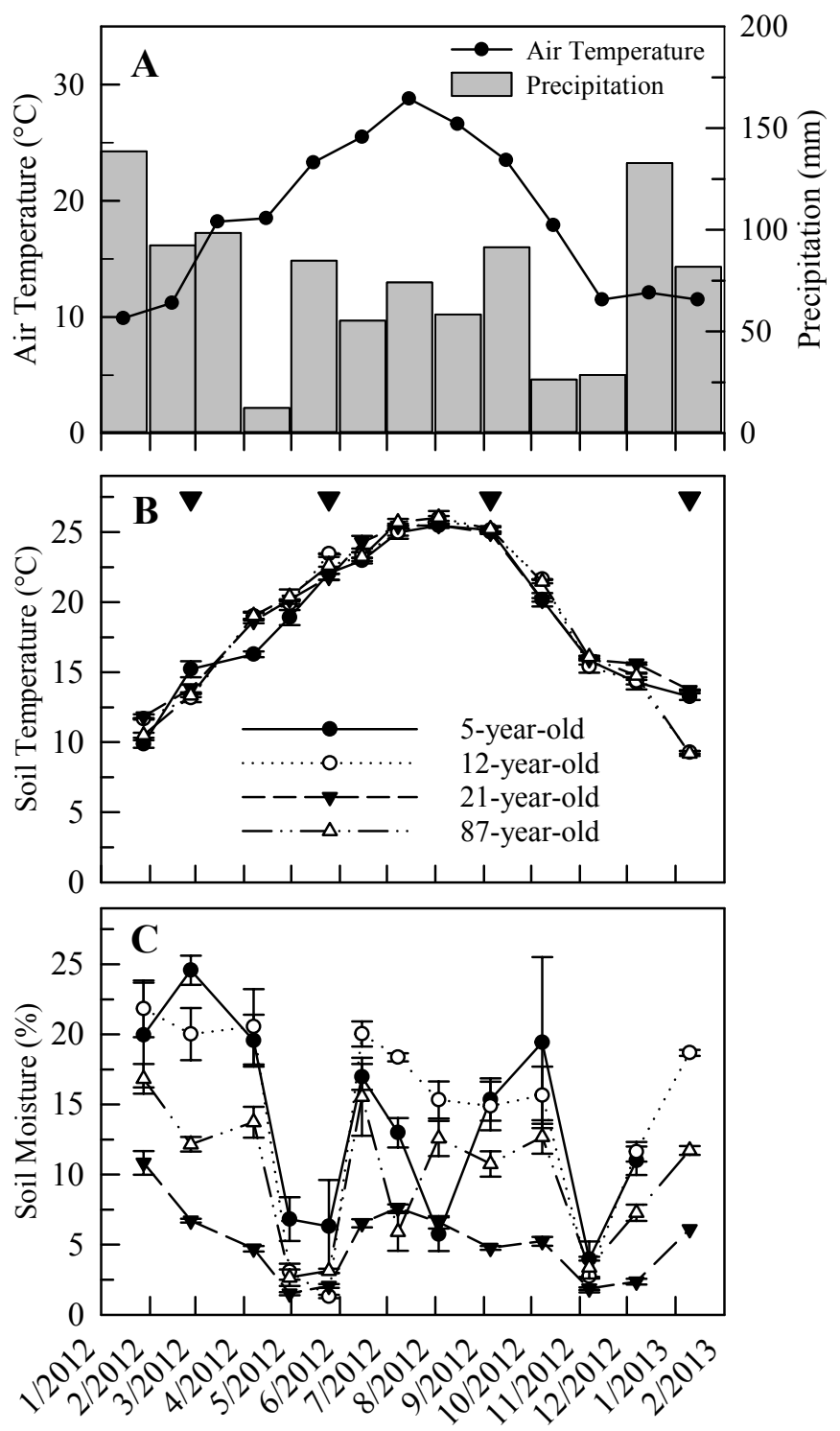

Date

Figure 1: (A) Mean air temperature and total precipitation by month at a Columbus, Georgia weather station (National Climatic Data Center 2015b). (B) Mean soil temperature and (C) soil moisture during soil respiration measurements in four longleaf pine stands varying in age and structure. Triangles represent dates of root biomass sampling and error bars are $\pm \mathrm{SE}$. 


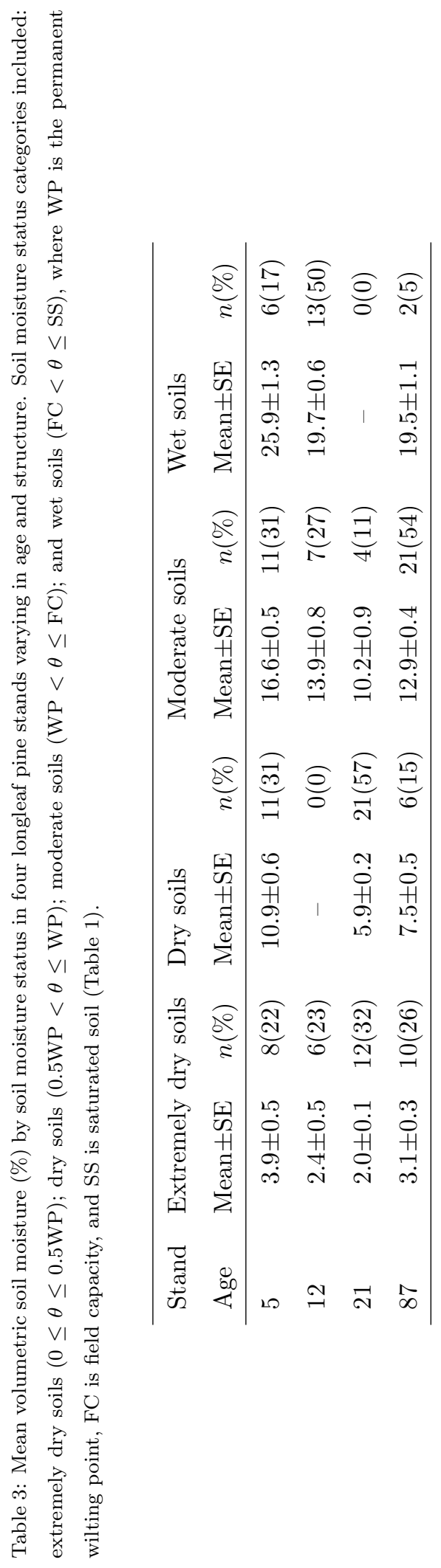



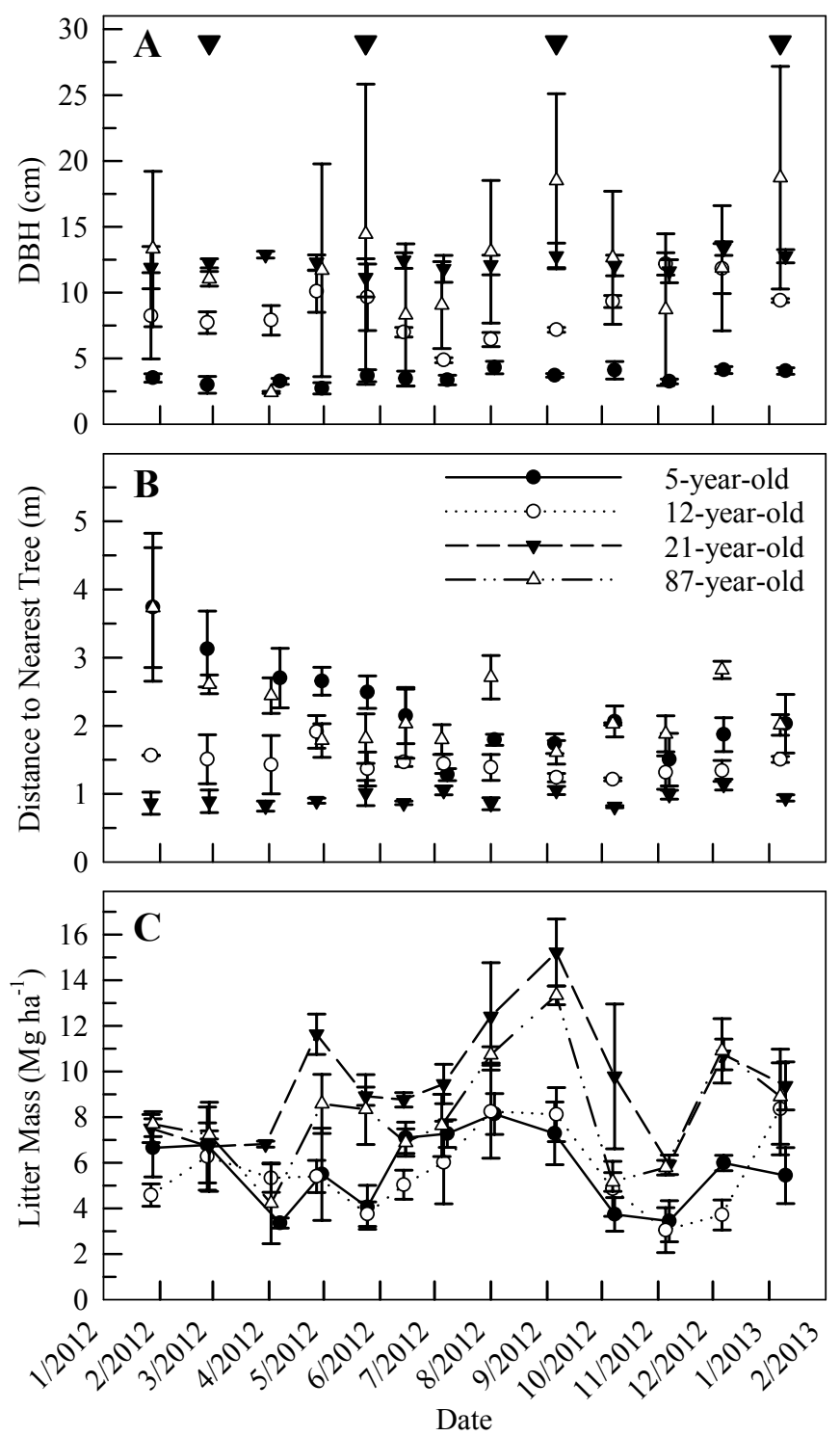

Figure 2: (A) Mean diameter at breast height $(\mathrm{DBH})$ of the nearest tree to soil respiration $\left(R_{\mathrm{S}}\right)$ collars, $(\mathrm{B})$ mean distance to nearest tree from $R_{\mathrm{S}}$ collars, and (C) litter mass by date in four longleaf pine stands varying in age and structure. Triangles represent dates of root biomass sampling and error bars are \pm SE. 

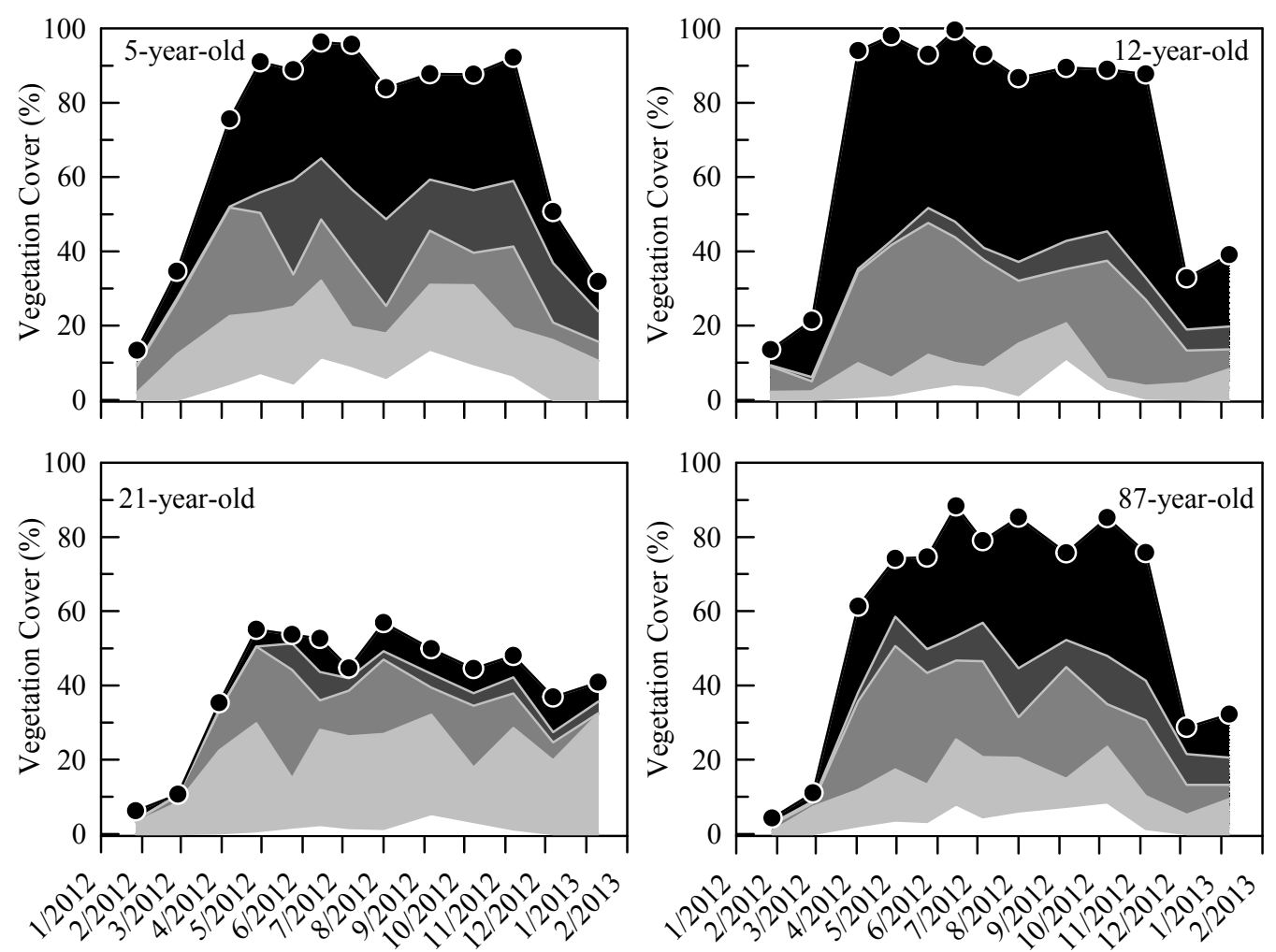

$1^{2} 2^{2} 3^{2} x^{2} 5^{2} 6^{2}+1^{2} 8^{2} 91^{2} 0^{2} 1^{2} 2^{2} 1^{2} 2^{2}$

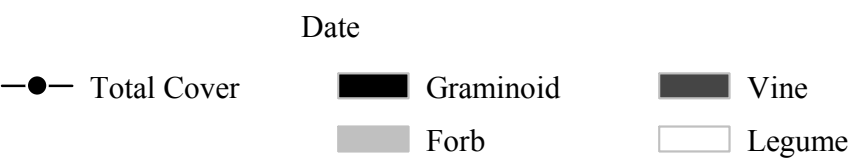

Date

Woody

Figure 3: Mean total vegetation cover and proportions of individual cover classes to total cover by date in four longleaf pine stands varying in age and structure. 

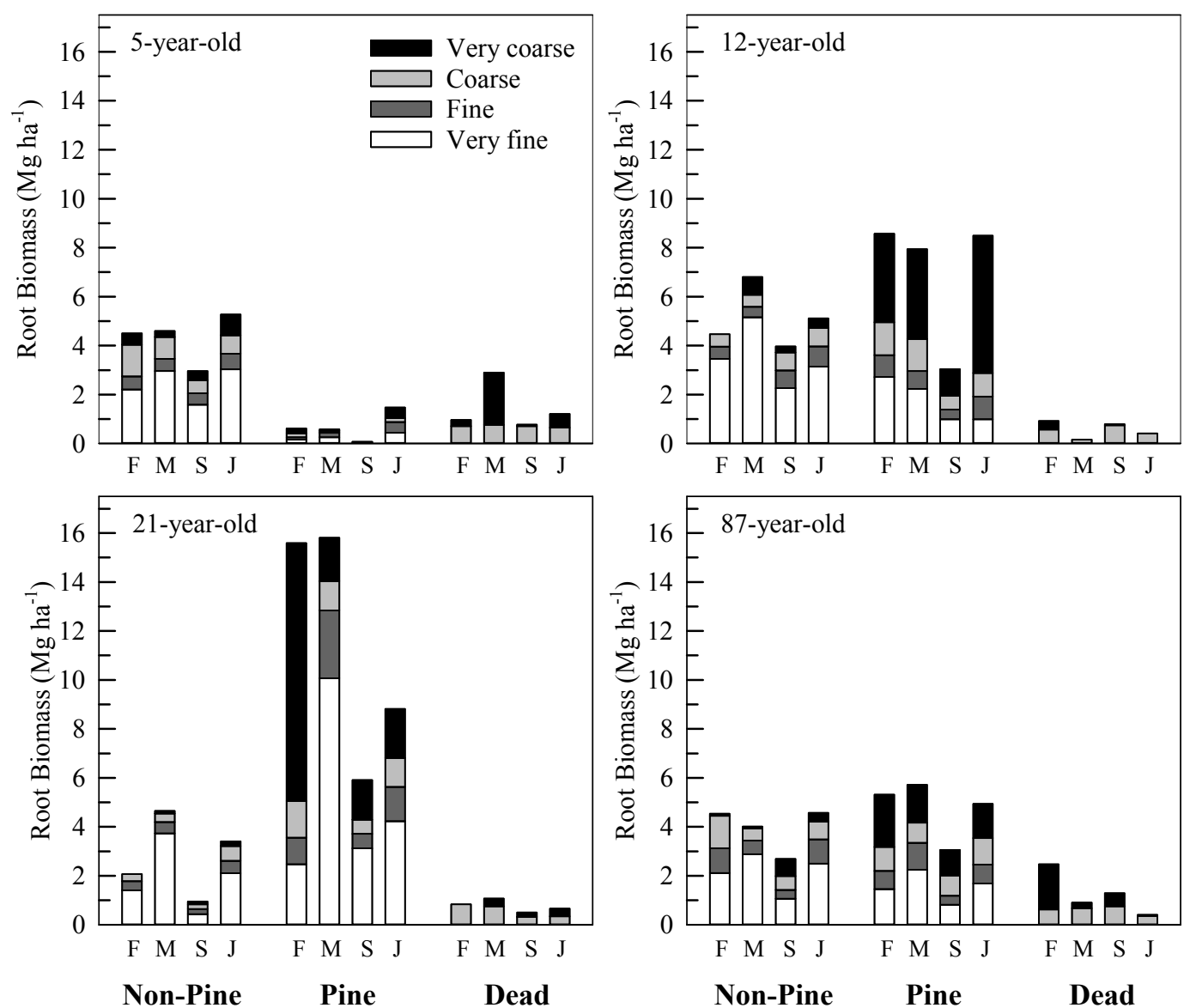

Figure 4: Mean root biomass for each root type by sampling month and size class in four longleaf pine stands varying in age and structure. Sampling months include February 2012 (F), May 2012 (M), September 2012 (S), and January $2013(\mathrm{~J})$. Size classes were determined by root diameter and include very fine roots $(\leq 1 \mathrm{~mm})$, fine $(>1$ and $\leq 2 \mathrm{~mm})$, coarse $(>2$ and $\leq 5 \mathrm{~mm})$, and very coarse $(>5 \mathrm{~mm})$. 

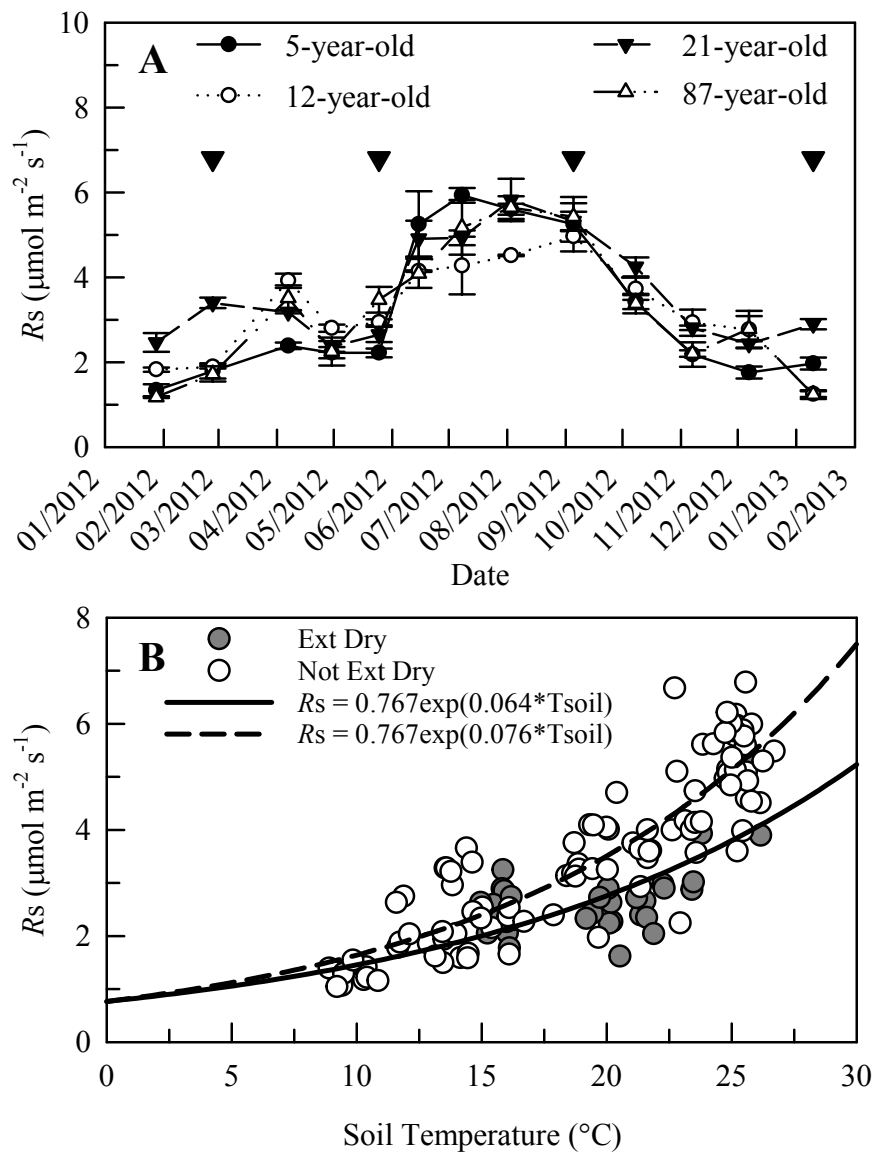

Figure 5: (A) Mean monthly soil respiration $\left(R_{\mathrm{S}}\right)$ by date in four longleaf pine stands varying in age and structure. Triangles represent dates of root biomass sampling and error bars are \pm SE. (B) Soil respiration versus soil temperature for two soil moisture $(\theta)$ categories. Ext Dry, extremely dry soils $(\theta \leq 0.5 \mathrm{WP})$; Not Ext Dry, dry, moderate, or wet soils $(\theta>0.5 \mathrm{WP})$, where $\mathrm{WP}$ is wilting point.

\subsection{Relationships between $\mathrm{Rs}$ and abiotic and biotic variables in longleaf pine stands}

With all stands and seasons pooled together, mean monthly $R_{\mathrm{S}}$ ranged from 1.18 to 5.94 $\mu \mathrm{mol} \mathrm{m}{ }^{-2} \mathrm{~s}^{-1}$ (Fig. 5A). Soil respiration generally followed the seasonal trend in soil temperature and increased exponentially with increasing soil temperature (Figs. $1 \mathrm{~B}$ and 5A). Across all the stands and on an annual basis, the temperature sensitivity $\left(Q_{10}\right)$ of $R_{\mathrm{S}}$ was 2.18 (AICC = $66.43)$ and the relationship, as modeled with Eq. (1), was $R_{\mathrm{S}}=0.680 * \exp \left(0.079 \mathrm{~T}_{\text {soil }}\right)$. Annual $R_{\mathrm{S}}$ calculated from linear interpolation across individual measurement periods was $12.0 \pm 0.9$, $12.3 \pm 0.7,13.9 \pm 0.7$, and $12.34 \pm 1.0 \mathrm{Mg} \mathrm{ha}^{-1}$ year $^{-1}$ in the 5 -, $12-, 21$-, and 87-year-old stands, respectively.

Categorization of soil moisture measurements based on stand-specific soil water status suggested 
Table 4: The probabilities of the linear relationships between temperature-normalized soil respiration $\left(R_{\text {norm }}\right)$ and the stand structural variables of each subplot $(n=138)$ in four longleaf pine stands varying in age and structure. Unstructured covariance structures were used to model the random coefficients.

\begin{tabular}{rrrrrrrrr}
\hline Variable $^{\mathrm{a}}$ & DBH & BA & QMD & Dens. $^{\text {b }}$ & SDI & Age & Sand & Clay \\
\hline $\mathrm{df}$ & 12 & 12 & 12 & - & 12 & 12 & 12 & 12 \\
$t$-value & 2.02 & 1.96 & 0.88 & - & 2.04 & -1.09 & 1.96 & -1.82 \\
$p$-value & 0.07 & 0.07 & 0.40 & - & 0.06 & 0.30 & 0.07 & 0.09 \\
AICC & -32.3 & -18.8 & -8.0 & - & -16.0 & -4.8 & -30.1 & -24.8
\end{tabular}

${ }^{a} \mathrm{DBH}$, mean diameter at breast height; BA, subplot basal area; QMD, quadratic mean

diameter; Dens., subplot tree density; SDI, Reineke's stand density index; Age, stand age; Sand, soil sand percentage; Clay, soil clay percentage.

b Tree density model did not converge regardless of covariance structure.

that soil moisture limited $R_{\mathrm{S}}$ at levels below half the wilting point (extremely dry conditions, Fig.5B). When the parameters for Eq. (1) were compared between soil moisture categories, $Q_{10}$ was significantly reduced under extremely dry soil conditions $\left(\mathrm{Q}_{10}=1.90\right)$ compared to all other soil moisture conditions $\left(\mathrm{Q}_{10}=2.14\right)$, while basal $R_{\mathrm{S}}$ was the same under all soil moisture conditions:

$$
\theta=\left\{\begin{array}{rll}
\text { Extremely dry } & : & R_{\mathrm{S}}=0.767 * \exp \left(0.064 \mathrm{~T}_{\text {soil }}\right) \\
\text { Not extremely dry } & : & R_{\mathrm{S}}=0.767 * \exp \left(0.076 \mathrm{~T}_{\text {soil }}\right)
\end{array}\right.
$$

Based on the sum of squares reduction test (Eq. 2), this model accounted for the same variation as the full model (Eq. 3. $\mathrm{F}_{5,130}=1.57, p=0.17$ ), and was a better fit for the data compared to Eq. (1) based on minimizing corrected AIC (-97.75).

The linear relationships between $R_{\text {norm }}$ and stand structural variables were not significant (Table 4). The linear relationships between $R_{\text {norm }}$ and distance to nearest tree, fine pine root biomass, and coarse pine root biomass were significant (Tables 5 and 6). Distance to nearest tree was negatively related with $R_{\text {norm }}$, and fine and coarse pine root biomass were positively related with $R_{\text {norm }}$ (Fig. 6). When the distance to the nearest tree was farther than $1.7 \mathrm{~m}$, observed $R_{\mathrm{S}}$ was lower than expected based on observed soil temperature (Fig. 6A). When fine and coarse pine root biomass was higher than 1.2 and $1.1 \mathrm{Mg} \mathrm{ha}^{-1}$, respectively, observed $R_{\mathrm{S}}$ was higher than expected based on soil temperature (Figs. $6 \mathrm{~B}$ and $6 \mathrm{C}$ ). 


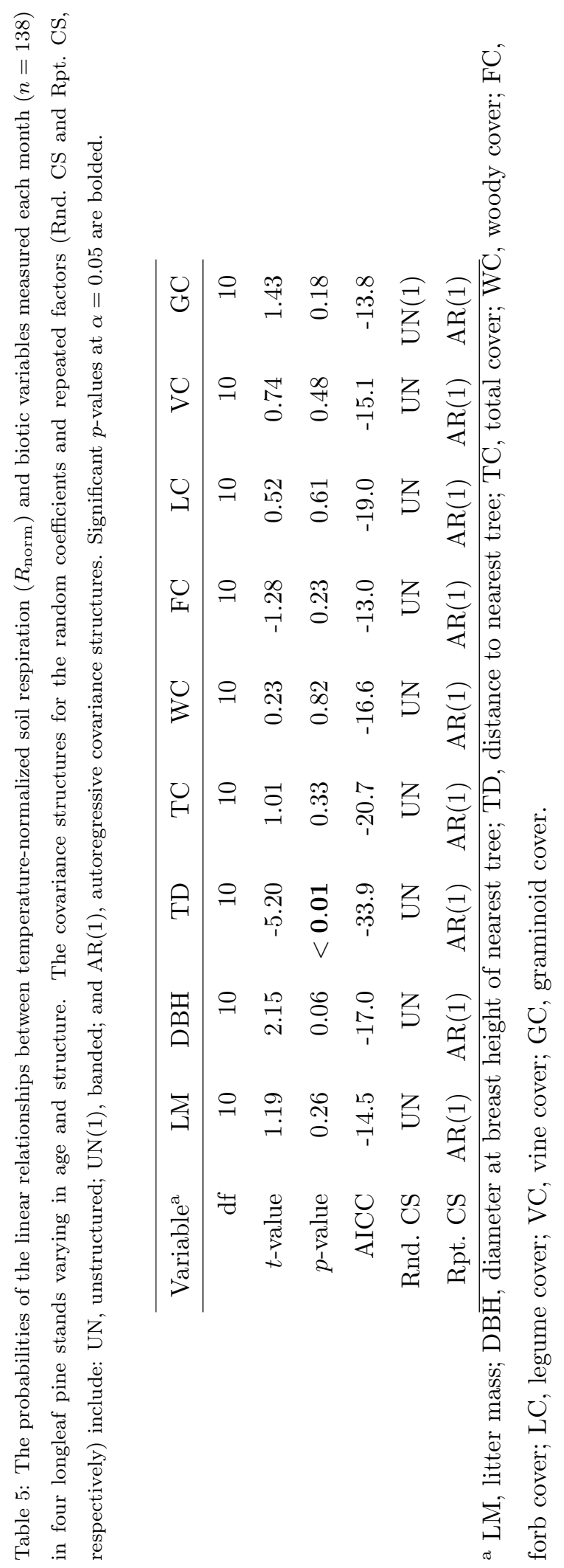




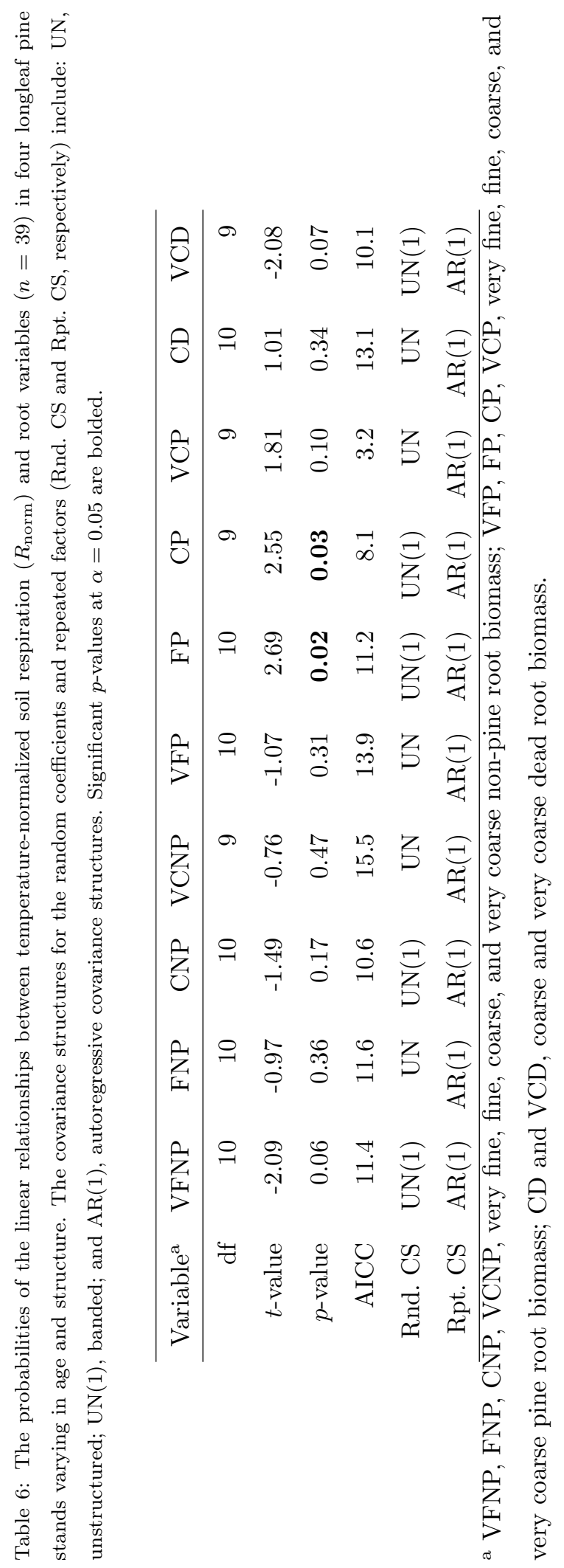



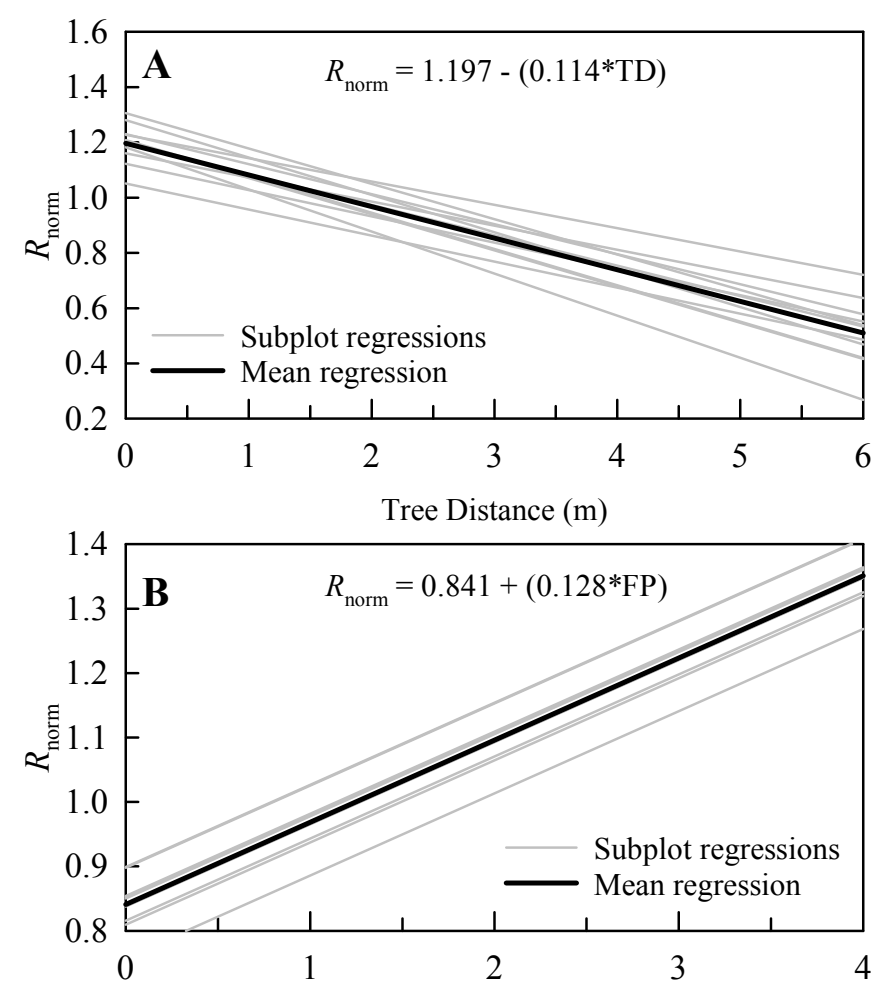

Fine Pine Root Biomass $\left(\mathrm{Mg} \mathrm{ha}^{-1}\right)$

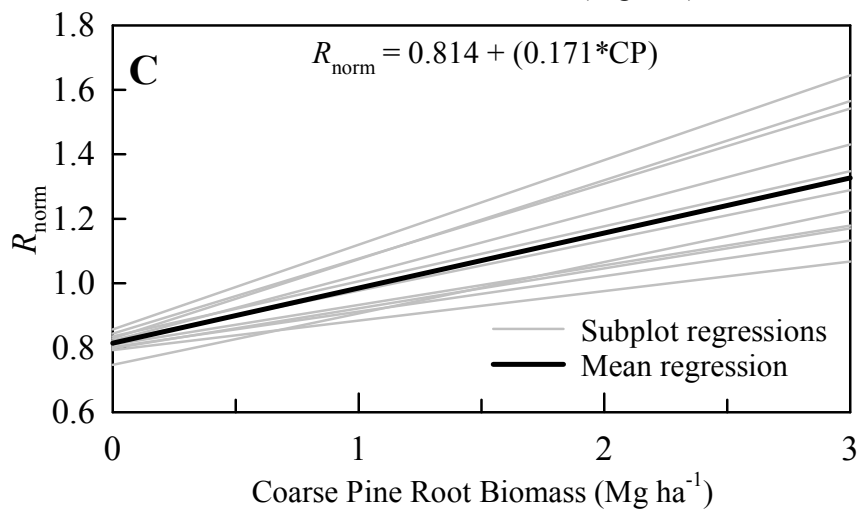

Figure 6: Temperature-normalized soil respiration $\left(R_{\text {norm }}\right)$ versus (A) distance to nearest tree from $R_{\mathrm{S}}$ collar, (B) fine pine root biomass, and $(\mathrm{C})$ coarse pine root biomass. Individual subplot regression lines shown in grey and mean regression line shown in black. TD, tree distance; FP, fine pine root biomass; $\mathrm{CP}$, coarse pine root biomass. 


\section{Discussion}

Over the 13-month study period and across four heterogeneous longleaf pine stands, the $Q_{10}$ of $R_{\mathrm{S}}$ was 2.18. Our results suggest that the apparent temperature response of $R_{\mathrm{S}}$ was significantly lower during periods of drought-like soil conditions than during periods of non-limiting soil moisture. Soil moisture has also been shown to affect the $Q_{10}$ of $R_{\mathrm{S}}$ in laboratory incubations Reichstein et al. 2005c) and in experimental drought studies in mixed deciduous forests (Borken et al. 2006) and old-field grasslands (Chen et al. 2011). Georgia was under drought stress for most months of this study, and 2012 was cited as the tenth driest year on record for Georgia National Climatic Data Center, 2012). However, low soil moisture modified the $R_{\mathrm{S}}$-temperature model only when soil temperature was relatively high, as evidenced by changes to the $Q_{10}$ parameter but not the basal $R_{\mathrm{S}}$ parameter of Eq. (1). This finding agrees with Concilio et al. (2006), who found that soil moisture limited $R_{\mathrm{S}}$ only during periods of high soil temperature and low soil moisture in a fire-dependent old-growth mixed forest of the Sierra Nevada Mountains, and work by Davidson et al. (2006), who concluded that drought can reduce $R_{\mathrm{S}}$ during the growing season in temperate ecosystems when evapotranspiration may exceed precipitation, as it did in our study (i.e. negative 3-month Standardized Precipitation Evapotranspiration Index for May through August 2012; National Climatic Data Center, 2014).

Limitations to estimating the apparent $Q_{10}$ from empirical models based on observational field data are well documented (e.g. Reichstein et al. 2005a|b, Davidson et al., 2006 Reichstein and Beer, 2008: Bahn et al. 2010b). Specifically, estimating $Q_{10}$ based on a first-order exponential function simplifies the phenological effects of substrate supply on $R_{\mathrm{S}}$ (Davidson et al. 2006, DeForest et al. 2006) and ignores the diurnal hysteresis between $R_{\mathrm{S}}$ and soil temperature (Reichstein et al. 2005c). Estimating $Q_{10}$ values based on the first-order exponential function may also result in a wide range of apparent $Q_{10}$ values between ecosystem types due to the correlation between the parameters (Reichstein et al. 2005b). These limitations of $Q_{10}$ reduce the utility of comparing $Q_{10}$ values between studies, however, Eq. (1) has also been shown to be adequate for evaluating the apparent temperature response of $R_{\mathrm{S}}$ over a normal temperature profile (Reichstein and Beer, 2008 Lellei-Kovács et al., 2011), which was the case in 2012 during this study (the range of monthly air temperature was similar to the 30-year-average air temperature range) (National Climatic Data Center, 2015a b). Although the first-order exponential model is used in this study primarily to highlight the threshold-like interaction between soil moisture and $Q_{10}$, comparing $Q_{10}$ across studies or ecosystems and drawing conclusions about the physiological response of $R_{\mathrm{S}}$ to temperature from simplified $Q_{10}$ parameters is not recommended (Reichstein et al., 2005c 
Reichstein and Beer, 2008).

Previous studies have stressed the importance of empirical models that describe the interactive roles of soil temperature and moisture on $R_{\mathrm{S}}$ (Dilustro et al., 2005, Lellei-Kovács et al., 2011 Moyano et al. 2012), and our results indicate the importance of relating volumetric soil moisture to soil-specific, texture-derived soil water potential, particularly when $R_{\mathrm{S}}$ is compared across a range of soil textures. Although the influence of soil moisture on $R_{\mathrm{S}}$ was evident at high soil temperatures when related to the wilting point properties of the various soil textures across these stands, no linear relationship was detected when volumetric soil moisture was regressed directly against $R_{\mathrm{S}}$. Volumetric soil moisture is easy to measure with portable devices and is more commonly researched in relation to $R_{\mathrm{S}}$ than is texture-derived soil water potential (e.g. Borken et al., 2006, Reichstein and Beer, 2008; Balogh et al., 2011, Ceccon et al., 2011, Lellei-Kovács et al., 2011, Barron-Gafford et al. 2014), but water availability for root, mycorrhizae, and microbial uptake is dependent not only on the volumetric quantity of soil water, but also upon its sorption to soil particles (Saxton and Rawls, 2006). For instance, almost twice the volumetric soil moisture must be present in the relatively clay-rich 5-year-old stand to reach wilting point (13\%) compared to the sandier 21-year-old stand (7.0\%; Table 1).

In addition to soil temperature and moisture, substrate supply (i.e. quality, quantity and timing of carbon sources allocated to roots and microbes through photosynthesis, root exudation, and litter) is a large contributor to variation observed in $R_{\mathrm{S}}$, and the effect of substrate supply on $R_{\mathrm{S}}$ is often evaluated through relationships between $R_{\mathrm{S}}$ and biotic variables (Davidson et al. 2006). Our second hypothesis that biotic variables would account for variation in $R_{\mathrm{S}}$ beyond the seasonal influence of soil temperature was supported by the relationships with $R_{\text {norm }}$ and distance to nearest tree and pine root biomass. Isolating the direct influence of stand structural variables (e.g. age, basal area) on $R_{\mathrm{S}}$ is challenging in longleaf pine forests because of covarying ecological factors, and our results indicated no significant relationship between temperature-normalized $R_{\mathrm{S}}$ and stand structural variables. However, fine pine root mass was significantly related to pine basal area in these stands in another study (Samuelson et al., 2014). So, although no direct relationship was found between $R_{\text {norm }}$ and stand structural variables, the relationships between $R_{\text {norm }}$ and pine root biomass and distance to nearest tree may be indirectly related to the influence of stand structure on $R_{\mathrm{S}}$. Similarly, distance to nearest tree was negatively related to $R_{\mathrm{S}}$ in a 22-year-old longleaf pine forest (Clinton et al., 2011), and $R_{\mathrm{S}}$ was significantly higher closer to the base of loblolly trees in plantations varying in age (Wiseman and Seiler, 2004). Total root volume, although not root biomass, positively related to temperature-normalized $R_{\mathrm{S}}$ in the same study (Wiseman and Seiler, 2004). Root biomass was also related to $R_{\mathrm{S}}$ in a slash pine ( $P$. elliottii Engelm.) plantation 
(Fang et al., 1998) and in 50-year-old longleaf pine stands varying in basal area (Samuelson and Whitaker, 2012).

On the other hand, we expected that litter mass and understory cover would positively relate to $R_{\text {norm }}$, but this was not supported. Soil respiration has been shown to be positively related to litter mass and understory ground cover (e.g. Ma et al., 2005, Fleming et al., 2006; Oishi et al., 2013). But, in longleaf pine forests (Samuelson and Whitaker, 2012) and slash pine forests (Fang et al. 1998), the effects of these vegetation variables on $R_{\mathrm{S}}$ were relatively small compared to the influence of soil temperature. Litter mass, understory cover by class, and non-pine roots were not related to $R_{\text {norm }}$ in this study, but were all significantly correlated with soil temperature (data not shown). This suggests that the seasonal variation of $R_{\mathrm{S}}$ may be captured with a simple exponential model in these stands. So, despite variability in age, forest structure, soil textures, ground cover, and root biomass observed among stands, relationships between $R_{\mathrm{S}}$ and biotic variables were marginal after first isolating the seasonal influence of soil temperature, which is perhaps a function of tight coupling between the seasonal availability of substrate and soil temperature (Davidson et al., 2006 Bahn et al., 2010a).

To our knowledge, no other study has comprehensively quantified $R_{\mathrm{S}}$ in longleaf pine ecosystems across such a range in stand structures. We found that annual $R_{\mathrm{S}}$ varied at most $14 \%$ between stands (5- and 21-year-old stands) and was $12.6 \mathrm{Mg} \mathrm{ha}^{-1}$ year $^{-1}$ of $\mathrm{C}$ on average across stands. Our annual $R_{\mathrm{S}}$ values are within the range of 11.0 to $17.9 \mathrm{Mg} \mathrm{ha}^{-1}$ year $^{-1}$ of $\mathrm{C}$ reported for 50 -year-old longleaf pine stands in southern Alabama varying in basal area from 7 to $36 \mathrm{~m}^{2} \mathrm{ha}^{-1}$ (Samuelson and Whitaker, 2012), but higher than those estimated for longleaf pine forests across an edaphic gradient (4.6 to $6.8 \mathrm{Mg} \mathrm{ha}^{-1}$ year $^{-1}$ of C) (Hendricks et al., 2006) and for 85 to 95-year-old longleaf pine savannas under control and irrigation treatments on xeric soils (6.5 to $7.1 \mathrm{Mg} \mathrm{ha}^{-1} \mathrm{year}^{-1}$ of C) (Ford et al., 2012). In contrast to our results, Samuelson and Whitaker (2012) found that annual $R_{\mathrm{S}}$ across stands related positively with mean annual litter mass, which varied from 6 to $18 \mathrm{Mg} \mathrm{ha}^{-1}$ compared to the smaller range observed in our study (5.6 to $9.5 \mathrm{Mg} \mathrm{ha}^{-1}$ ). Respiration from the litter layer of the forest floor has been found to be $22 \%$ of $R_{\mathrm{S}}$ in 20 -year-old South Carolina longleaf pine stands (Reinke et al. 1 1981) and up to $26 \%$ of $R_{\mathrm{S}}$ in North Carolina loblolly pine plantations (Taneva and Gonzalez-Meler, 2011). In both Ford et al. (2012) and Hendricks et al. (2006), which were completed at the same research center in southwest Georgia, lower annual $R_{\mathrm{S}}$ was likely due to negligible litter mass because of frequent, 2 year burn intervals.

In conclusion, the goal of this study was to explore the intra-annual variation in $R_{\mathrm{S}}$ and related abiotic and biotic variables across four diverse longleaf pine stands. Mean monthly $R_{\mathrm{S}}$ was related most strongly to soil temperature and reduced during periods of drought stress, but 
drought stress was only detected when volumetric soil moisture was related to texture-derived water potential. Longleaf pine forests occupy a wide edaphic range (Burns and Honkala, 1990) and thus consideration of soil texture in future longleaf pine $R_{\mathrm{S}}$ studies is warranted. Longleaf pine restoration efforts require plantation establishment to achieve the goal to increase the area of longleaf pine to 5.2 million ha by 2027 (America's Longleaf Restoration Initiative, 2014). Longleaf pine is typically planted at a lower density than other southern pine species, and when coupled with moderate survival forms a mosaic of tree spacing and tree sizes. Accordingly, broad scale stand structural variables such as age and basal area were not related to $R_{\text {norm}}$, but the distance to nearby trees and pine root biomass did relate to $R_{\text {norm }}$ when measured concurrently with $R_{\mathrm{S}}$ measurements. The dampening of $R_{\mathrm{S}}$ at high soil temperature by low soil water availability indicates that temperature and precipitation will be important in understanding the contribution of $R_{\mathrm{S}}$ to ecosystem respiration and the carbon sink potential of longleaf pine forests.

\section{Acknowledgements}

This research was supported by the United States Department of Defense through the Strategic Environmental Research and Development Program (SERDP) and the School of Forestry \& Wildlife Sciences, Auburn University. The authors thank Tom Stokes, Jake Blackstock, Justin Rathel, Michael Gunter, Ann Huyler, Joe Clark, and Lorenzo Ferrari for assistance in data collection and James Parker and Brian Waldrep from Fort Benning, Land Management Division for their support. We also appreciate the statistical assistance provided by Greg Somers and Zhaofei Fan.

\section{References}

America's Longleaf Restoration Initiative, 2014. 2014 Range-wide Accomplishment Report. Online Article. http://www.americaslongleaf.org/resources/2014-range-wide-accomplishmentreport-and-executive-summary/. Downloaded April 23, 2015.

Archer, J.K., Miller, D.L., Tanner, G.W., 2007. Changes in understory vegetation and soil characteristics following silvicultural activities in a southeastern mixed pine forest. J. Torrey Botanical Society $134,489-504$.

Bahn, M., Janssens, I.A., Reichstein, M., Smith, P., Trumbore, S.E., 2010a. Soil respiration across scales: towards an integration of patterns and processes. New Phytol. 186, 292-296. 
Bahn, M., Reichstein, M., Davidson, E.A., Grünzweig, J., Jung, M., Carbone, M.S., Epron, D., Misson, L., Nouvellon, Y., Roupsard, O., Savage, K., Trumbore, S.E., Gimeno, C., Curiel Yuste, J., Tang, J., Vargas, R., Janssens, I.A., 2010b. Soil respiration at mean annual temperature predicts annual total across vegetation types and biomes. Biogeosciences 7, 2147-2157.

Bailey, R.G., 1994. Ecoregions of the United States. GIS shapefile. U.S. Department of Agriculture Forest Service.

Balogh, J., Pintér, K., Fóti, S., Cserhalmi, D., Papp, M., Nagy, Z., 2011. Dependence of soil respiration on soil moisture, clay content, soil organic matter, and $\mathrm{CO}_{2}$ uptake in dry grasslands. Soil Biol. Biochem. 43, 1006-1013.

Barron-Gafford, G.A., Cable, J.M., Bentley, L.P., Scott, R.L., Huxman, T.E., Jenerette, G.D., Ogle, K., 2014. Quantifying the timescales over which exogenous and endogenous conditions affect soil respiration. New Phytol. 202, 442-454.

Borken, W., Savage, K., Davidson, E.A., Trumbore, S.E., 2006. Effects of experimental drought on soil respiration and radiocarbon efflux from a temperate forest soil. Glob. Change Biol. 12, $177-193$.

Brockway, D.G., Loewenstein, E.F., Outcalt, K.W., 2014. Proporational basal area method for implementing selection silviculture systems in longleaf pine forests. Can. J. Forest Res. 44, $977-985$.

Burns, R.M., Honkala, B.H., 1990. Silvics of North America. United States Department of Agriculture Forest Service.

Ceccon, C., Panzacchi, P., Scandellari, F., Prandi, L., Ventura, M., Russo, B., Millard, P., Tagliavini, M., 2011. Spatial and temporal effects of soil temperature and moisture and the relation to fine root density on root and soil respiration in a mature apple orchard. Plant Soil 342, 195-206.

Chen, X., Post, W.M., Norby, R.J., Classen, A.T., 2011. Modeling soil respiration and variations in source components using a multi-factor global climate change experiment. Climatic Change $107,459-480$.

Clinton, B.D., Maier, C.A., Ford, C.R., Mitchell, R.J., 2011. Transient changes in transpiration, and stem and soil $\mathrm{CO}_{2}$ efflux in longleaf pine (Pinus palustris Mill.) following fire induced leaf area reduction. Trees 25, 997-1007. 
Concilio, A., Ma, S., Ryu, S.R., North, M., Chen, J., 2006. Soil respiration response to experimental disturbances over 3 years. Forest Ecol. Manag. 228, 82-90.

Davidson, E.A., Janssens, I.A., Luo, Y., 2006. On the variability of respiration in terrestrial ecosystems: moving beyond $\mathrm{Q}_{10}$. Glob. Change Biol. 12, 154-164.

DeForest, J.L., Noormets, A., McNulty, S.G., Sun, G., Tenney, G., Chen, J., 2006. Phenophases alter the soil respiration-temperature relationship in an oak dominated forest. Int. J. Biometeorol. $1,135-144$.

Dilustro, J.J., Collins, B., Duncan, L., Crawford, C., 2005. Moisture and soil texture effects on soil $\mathrm{CO}_{2}$ efflux components in southeastern mixed pine forests. Forest Ecol. Manag. 204, 87-97.

Fang, C., Moncrieff, J.B., Gholz, H.L., Clark, K.L., 1998. Soil $\mathrm{CO}_{2}$ and its spatial variation in a Florida slash pine plantation. Plant Soil 205, 135-146.

Fleming, R.L., Laporte, M.F., Hogan, G.D., Hazlett, P.W., 2006. Effects of harvesting and soil disturbances on soil $\mathrm{CO}_{2}$ efflux from a jack pine forest. Can. J. Forest Res. 36, 589-600.

Ford, C.R., McGee, J.D., Scandellari, F., Hobbie, E.A., Mitchell, R.J., 2012. Long- and short-term precipitation effects on soil $\mathrm{CO}_{2}$ efflux and total belowground carbon allocation. Agr. Forest Meteorol. 156, 54-64.

Garten, C.T., Ashwood, T.L., 2004. Land cover differences in soil carbon and nitrogen at Fort Benning, Georgia. Doc. ORNL/TM-2004/14. Oak Ridge National Laboratory, Oak Ridge, Tennessee.

Gaumont-Guay, D., Black, T.A., Griffis, T.J., Barr, A.G., Morgenstern, K., Jassal, R.S., Nesic, Z., 2006. Influence of temperature and drought on seasonal and interannual variations of soil, bole and ecosystem respiration in a boreal aspen stand. Agr. Forest Meteorol. 140, 203-219. doi $10.1016 / \mathrm{j}$. agrformet.2006.08.002.

Gomez-Casanovas, N., Anderson-Teixeira, K., Zeri, M., Bernacchi, C.J., DeLucia, E.H., 2013. Gap filling strategies and error in estimating annual soil respiration. Glob. Change Biol. 19, 1941-1952.

Hedman, C.W., Grace, S.L., King, S.E., 2000. Vegetation composition and structure of southern coastal plain pine forests: an ecological comparison. Forest Ecol. Manag. 134, 233-247. 
Heim, B., Seiler, J.R., Strahm, B.D., In Press. Root non-structural carbohydrates and their relationship with autotrophic respiration of loblolly pine (Pinus taeda L.). Commun. Soil Sci. Plan. Anal. XX, XXX-XXX.

Hendricks, J.J., Hendrick, R.L., Wilson, C.A., Mitchell, R.J., Pecot, S.D., Guo, D., 2006. Assessing the patterns and controls of fine root dynamics: an empirical test and methodological review. J. Ecol. 94, 40-57.

Hiers, J.K., Mitchell, R.J., Boring, L.R., Hendricks, J.J., Wyatt, R., 2003. Legumes native to longleaf pine savannas exhibit capacity for high $\mathrm{N}_{2}$-fixation rates and negligible impacts due to timing of fire. New Phytol. 157, 327-338.

Knorr, W., Prentice, I.C., House, J.I., Holland, E.A., 2005. Long-term sensitivity of soil carbon turnover to warming. Nature 433, 298-301.

Larkin, C.C., Kwit, C., Wunderle, Jr., J.M., Helmer, E.H., Stevens, M.H.H., Roberts, M.T.K., Ewert, D.N., 2012. Disturbance type and plant successional communities in Bahamian dry forests. Biotropica 44, 10-18. doi:10.1111/j.1744-7429.2011.00771.x.

Lavoie, M., Mack, M.C., Hiers, J.K., Pokswinski, S., 2012. The effect of restoration treatments on the spatial variability of soil processes under longleaf pine trees. Forests 3, 591-604.

Lellei-Kovács, E., Kovács-Láng, E., Botta-Dukát, Z., Kalapos, T., Emmett, B., Beier, C., 2011. Thresholds and interactive effects of soil moisture on the temperature response of soil respiration. Eur. J. Soil Biol. 47, 247-255.

Littell, R.C., Milliken, G.A., Stroup, W.W., Wolfinger, R.D., Schabenberger, O., 2006. SAS for Mixed Models. second ed.. SAS Institute, Inc., Cary, NC. chapter Random Coefficient Models. pp. 317-341.

Lovett, G.M., Cole, J.J., Pace, M.L., 2006. Is net ecosystem production equal to ecosystem carbon accumulation? Ecosystems 9, 152-155.

Ma, S., Chen, J., Butnor, J.R., North, M., Euskirchen, E.S., Oakley, B., 2005. Biophysical controls on soil respiration in the dominant patch types of an old-growth, mixed-conifer forest. Forest Sci. $51,221-232$.

Mahecha, M.D., Reichstein, M., Carvalhais, N., Lasslop, G., Lange, H., Seneviratne, S.I., Vargas, R., Ammann, C., Arain, M.A., Cescatti, A., Janssens, I.A., Migliavacca, M., Montagnani, L., 
Richardson, A.D., 2010. Global convergence in the temperature sensitivity of respiration at ecosystem level. Science 329, 838-840.

Maier, M., Schack-Kirchner, H., Hildebrand, E.E., Holst, J., 2010. Pore-space $\mathrm{CO}_{2}$ dynamics in a deep, well-aerated soil. Eur. J. Soil Sci. 61, 877-887.

Maier, M., Schack-Kirchner, H., Hildebrand, E.E., Schindler, D., 2011. Soil $\mathrm{CO}_{2}$ efflux vs. soil respiration: Implications for flux models. Agr. Forest Meteorol. 151, 1723-1730. doi:10.1016/ j.agrformet.2011.07.006.

McNab, W.H., Cleland, D.T., Freeouf, J.A., Keys Jr, J.E., Nowacki, G.J., Carpenter, C.A., 2005. Description of ecological subregions: sections of the conterminous United States. Technical Report. U.S. Department of Agriculture Forest Service.

Metcalfe, D.B., Fisher, R.A., Wardle, D.A., 2011. Plant communities as drivers of soil respiration: pathways, mechanisms, and significance for global change. Biogeosciences 8, 2047-2061.

Mitchell, R.J., Hiers, J.K., O'Brien, J.J., Jack, S.B., Engstrom, R.T., 2006. Silviculture that sustains: the nexus between silviculture, frequent prescribed fire, and conservation of biodiversity in longleaf pine forests of the southeastern United States. Can. J. Forest Res. 36, 2714-2736.

Moyano, F.E., Vasilyeva, N., Cook, F.J., Craine, J., Curiel Yuste, J., Don, A., Epron, D., Formanek, P., Franzluebbers, A., Ilstedt, U., Kätterer, T., Orchard, V.A., Reichstein, M., Rey, A., Ruamps, L., Subke, J.A., Thomsen, I.K., Chenu, C., 2012. The moisture response of soil heterotrophic respiration: interaction with soil properties. Biogeosciences 9, 1173-1182.

National Climatic Data Center, 2012. Drought - Annual 2012. State of the Climate Report. Last accessed January 21, 2015. http://www.ncdc.noaa.gov/sotc/drought/2012/13.

National Climatic Data Center, 2014. NIDIS Map and Data Viewer. Last accessed January 10, 2014. http://gis.ncdc.noaa.gov/map/drought/.

National Climatic Data Center, 2015a. 1981-2010 Normals. Columbus Metropolitan Airport, GA. Station GHCND:USW00093842. Last accessed January 15, 2015. http://www.ncdc.noaa.gov/cdo-web/datatools/normals.

National Climatic Data Center, 2015b. Daily Summaries. Columbus Metropolitan Airport, GA. Station GHCND:USW00093842. Downloaded November 2014. http://www.ncdc.noaa.gov/cdoweb/datatools/findstation. 
Noormets, A., Gavazzi, M.J., McNulty, S.G., Domec, J.C., Sun, G., King, J.S., Chen, J., 2010. Response of carbon fluxes to drought in a coastal plain loblolly pine forest. Glob. Change Biol. $16,272-287$.

Noss, R.F., 1988. The longleaf pine landscape of the Southeast: almost gone and almost forgotten. Endanger. Species Update 5, 1-8.

Novick, K.A., Oishi, A.C., Ward, E.J., Siqueira, M.B.S., Juang, J.Y., Stoy, P.C., 2014. On the difference in the net ecosystem exchange of $\mathrm{CO}_{2}$ between deciduous and evergreen forests in the southeastern United States. Glob. Change Biol. .

Oishi, A.C., Palmroth, S., Butnor, J.R., Johnsen, K.H., Oren, R., 2013. Spatial and temporal variability of soil $\mathrm{CO}_{2}$ efflux in three proximate temperate forest ecosystems. Agr. Forest Meteorol. 171-172, 256-269.

Oram, B., Nelson, R., 2014. Soil texture triangle: hydraulic properties calculator. www.staffweb.wilkes.edu/brian.oram/soilwatr.htm. Sourced from Saxton et al. 1986. Soil Sci. Soc. Amer. J. 50(4):1031-1036.

Orchard, V.A., Cook, F.J., 1983. Relationship between soil respiration and soil moisture. Soil Biol. Biochem. 15, 447-453.

Palmroth, S., Maier, C.A., McCarthy, H.R., Oishi, A.C., Kim, H.S., Johnsen, K.H., Katul, G.G., Oren, R., 2005. Contrasting responses to drought of forest floor $\mathrm{CO}_{2}$ efflux in a loblolly pine plantation and a nearby oak-hickory forest. Glob. Change Biol. 11, 421-434.

Raich, J.W., Nadelhoffer, K.J., 1989. Belowground carbon allocation in forest ecosystems: global trends. Ecology 70, 1346-1354.

Raich, J.W., Tufekcioglu, A., 2000. Vegetation and soil respiration: Correlations and controls. Biogeochemistry 48, 71-90.

Reichstein, M., Beer, C., 2008. Soil respiration across scales: the importance of a model-data integration framework for data interpretation. J. Plant Nutr. Soil Sci. 171, 344-354. doi-10. 1002/jpln.200700075

Reichstein, M., Falge, E., Baldocchi, D.D., Papale, D., Aubinet, M., Berbigier, P., Bernhofer, C., Buchmann, N., Gilmanov, T., Granier, A., Grünwald, T., Havránková, K., Ilvesniemi, H., Janous, D., Knohl, A., Laurila, T., Lohila, A., Loustau, D., Matteucci, G., Meyers, T., Miglietta, F., Ourcival, J.M., Pumpanen, J., Rambal, S., Rotenberg, E., Sanz, M., Tenhunen, J., Seufert, 
G., Vaccari, F., Vesala, T., Yakir, D., Valentini, R., 2005a. On the separation of net ecosystem exchange into assimilation and ecosystem respiration: review and improved algorithm. Glob. Change Biol. 11, 1424-1439.

Reichstein, M., Kätterer, T., Andreén, O., Ciasis, P., Schulze, E.D., Cramer, W., Papale, D., Valentini, R., 2005b. Temperature sensitivity of decomposition in relation to soil organic matter pools: critique and outlook. Biogeosciences 2, 317-321.

Reichstein, M., Subke, J.A., Angeli, A.C., Tenhunen, J.D., 2005c. Does the temperature sensitivity of decomposition of soil organic matter depend upon water content, soil horizon, or incubation time? Glob. Change Biol. 11, 1754-1767.

Reinke, J.J., Adriano, D.C., McLeod, K.W., 1981. Effects of litter alteration on carbon dioxide evolution from a South Carolina pine forest floor. Soil Sci. Soc. Am. J. 45, 620-623.

Runion, G.B., Butnor, J.R., Prior, S.A., Mitchell, R.J., Rogers, H.H., 2012. Effects of atmospheric $\mathrm{CO}_{2}$ enrichment on soil $\mathrm{CO}_{2}$ efflux in a young longleaf pine system. Int. J. Agron. 2012, 1-9.

Ryan, M.G., Law, B.E., 2005. Interpreting, measuring, and modeling soil respiration. Biogeochemistry $73,3-27$.

Samuelson, L.J., Johnsen, K.H., Stokes, T.A., Lu, W., 2004. Intensive management modifies soil $\mathrm{CO}_{2}$ efflux in 6-year-old Pinus taeda L. stands. Forest Ecol. Manag. 200, 335-345.

Samuelson, L.J., Mathew, R., Stokes, T.A., Feng, Y., Aubrey, D.P., Coleman, M., 2009. Soil and microbial respiration in a loblolly pine plantation in response to seven years of irrigation and fertilization. Forest Ecol. Manag. 258, 2431-2438.

Samuelson, L.J., Stokes, T.A., Butnor, J.R., Johnsen, K.H., Gonzalez-Benecke, C.A., Anderson, P., Jackson, J., Ferrari, L., Martin, T.A., Cropper Jr, W.P., 2014. Ecosystem carbon stocks in Pinus palustris forests. Can. J. Forest Res. 44, 476-486.

Samuelson, L.J., Whitaker, W.B., 2012. Relationships between soil $\mathrm{CO}_{2}$ efflux and forest structure in 50-year-old longleaf pine. Forest Sci. 58, 472-484.

Saxton, K.E., Rawls, W.R., 2006. Soil water characteristic estimates by texture and organic matter for hydrologic solutions. Soil Sci. Soc. Am. J. 70, 1569-1578.

Soil Survey Staff, 2014. Web soil survey. Online. http://websoilsurvey.nrcs.usda.gov. Accessed January 2012. 
Subke, J.A., Bahn, M., 2010. On the 'temperature sensitivity' of soil respiration: Can we use the immeasurable to predict the unknown? Soil Biol. Biochem. 42, 1653-1656.

Taneva, L., Gonzalez-Meler, M.A., 2011. Distinct patterns in the diurnal and seasonal variability in four components of soil respiration in a temperate forest under free-air $\mathrm{CO}_{2}$ enrichment. Biogeosciences 8, 3077-3092.

Tjoelker, M.G., Craine, J.M., Wedin, D., Reich, P.B., Tilman, D., 2005. Linking leaf and root trait syndromes among 39 grassland and savannah species. New Phytol. 167, 493-508.

Tyree, M.C., Seiler, J.R., Maier, C.A., 2014. Contrasting genotypes, soil amendments, and their interactive effects on short-term total soil $\mathrm{CO}_{2}$ efflux in a 3-year-old Pinus taeda L. plantation. Soil Biol. Biochem. 69, 93-100.

van Hees, P.A.W., Jones, D.L., Finlay, R., Godbold, D.L., Lundström, U.S., 2005. The carbon we do not see-the impact of low molecular weight compounds on carbon dynamics and respiration in forest soils: a review. Soil Biol. Biochem. 37, 1-13.

VanderSchaaf, C.L., 2013. Reineke's stand density index: a quantitative and non-unitless measure of stand density, in: Proceedings of the 15th biennial southern silvicultural research conference, Asheville, NC: U.S. Department of Agriculture, Forest Service, Southern Research Station. pp. $577-579$.

Wiseman, P.E., Seiler, J.R., 2004. Soil $\mathrm{CO}_{2}$ efflux across four age classes of plantation loblolly pine (Pinus taeda L.) on the Virginia Piedmont. Forest Ecol. Manag. 192, 297-311.

Zhou, T., Shi, P., Hui, D., Luo, Y., 2009. Global pattern of temperature sensitivity of soil heterotrophic respiration $\left(\mathrm{Q}_{10}\right)$ and its implications for carbon-climate feedback. J. Geophys. Res. $114,1-9$. 